\title{
Analysis of The Influence of Timely Submission of Financial Statements of Transportation Companies Listed on The Indonesia Stock Exchange 2017-2021
}

\author{
Rahmat Putra Ahmad Hasibuan', Nur Fadhilah Ahmad Hasibuan² \\ ${ }_{1}$ Universitas Islam Negeri Fatmawati Soekarno, Bengkulu, Indonesia \\ ${ }^{2}$ Universitas Islam Negeri Sumatera Utara, Medan, Indonesia \\ Corresponding Author: rahmatputrahasibuan@gmail.com
}

ABSTRACT
The objective of the research was to find out and to analyze the influence
profitability, leverage, liquidity, company size, auditor opinion and and
KAP reputation partially on the timeliness of the submission of financial
statements to transportation companies listed on the Indonesia Stock
Exchange. The population in this study were 30 transportation companies
listed in the Indonesia Stock Exchange in the period of 2017 - 2021. Samples
were selected using saturated samples where all populations were included
as samples. Data were processed using logistic regression test at a
significance level of 5 percent using SPSS. The results of the study found
empirical evidence that the variables of profitability, liquidity and auditor
opinion affect the timeliness of the submission of financial statements.
while the leverage variable, company size and KAP reputation do not have
a significant effect on the timeliness of the submission of financial
statements.

Keywords

Profitability, Leverage, Liquidity, Company Size, Auditor Opinion

\section{INTRODUCTION}

The current development of the capital market in Indonesia has increased and competition in the business world is increasingly competitive. The company's progress is greatly influenced by the availability of the company's own funds and investors who want to invest in the company. The capital market provides opportunities for companies to compete in a healthy manner. This encourages companies to improve the quality of their company's financial statements in accordance with Financial Accounting Standards. Information produced by financial statements will be very useful for users of financial statements, especially for investors if the information is presented in a timely and accurate manner. Timeliness can also affect the relevance of financial information presented so that it has benefits for users of information, while financial information is said to be irrelevant in the event of a delay in the submission of financial statements. Companies listed on the Indonesia Stock Exchange must comply with the regulations stipulated in Law No.8 of 1995 concerning the Capital Market regarding compliance with the timeliness of financial reporting 
which clearly states that public companies are required to submit periodic reports and incidental reports. On August 1, 2012 Bapepam tightened regulations with the issuance of Bapepam and LK Decree Number: KEP - 431 / BL / 2012 with Attachment Number XK6 concerning Submission of Annual Report of Issuers or Public Companies whose registration statement has become effective must submit annual financial reports to the Service Authority Financial (OJK) and LK at the end of the fourth month (120 days) after the financial year ends. In addition, issuers or public companies must submit an annual report on the website (website) of the issuer or public company together with the submission of the annual report to the Financial Services Authority (OJK) and LK.

Since December 12, 2012, Bapepam has changed its name to the Financial Services Authority (OJK) as the Capital Market Supervisory Agency in Indonesia. The Financial Services Authority Regulation Number 29 / POJK.04 / 2016 also explains that the annual financial statements and audited financial statements must be submitted to the OJK with the end of the fourth month (120 days) after the date the company books close. OJK also stated that the decision of Bapepam and LK Number KEP-431 / BL / 2012 dated 1 August 2012 concerning the Submission of the Annual Report of Issuers or Public Companies along with Regulation Number X.K.6 which is attached, revoked and declared invalid on 1 January 2017 Cases of company delays in submitting financial reports to the Financial Services Authority still occur frequently, even though OJK and LK have extended the period of submission of financial statements. Recorded throughout 2011, the OJK handled 54 cases of late submission of financial statements that hit public companies on the stock exchange. In 2012 the OJK handled 74 cases of company financial statements delays. In 2013 the OJK handled 30 cases of late company financial statements. In 2015, the OJK handled 52 cases of delays in the company's financial statements as of December 2014. This indicates that almost every year the book closes, many public companies are found late in submitting annual financial reports. OJK in Kompas.com (08/03/2015) also stated firm action if the company is late in submitting the report and will be subject to sanctions according to the rules, namely a fine of Rp.1,000,000 per day. So far, there has been no action from the FSA that gives relief for the delay in submitting financial statements, all of which will be dealt with according to the rules. This is because the financial statements are important for investors and investors needing financial report data quickly, seeing that the capital market moves dynamically every minute, then the timeliness of submitting financial statements is very necessary.

The research objective achieved in this study was to test and analyze the effect of profitability, leverage, liquidity, firm size, auditor opinion, and 
reputation of KAP on the timeliness of submission of financial statements to transportation companies listed on the Indonesia Stock Exchange. Agency theory is a theory that explains the relationship between agents as the party that manages the company and the principal as the owner of both parties are bound in a contract. According to Jensen and Meckling (1976) explain the agency relationship in agency theory that the company is a collection of contracts (nexus of contract) between the owner of economic resources (principal) and the manager (agent) who takes care of the use and control of these resources. Management is a party contracted by shareholders to work in the interests of shareholders. For this reason, management is given part of the power to make decisions for the best interests of shareholders. Therefore, management must account for all its efforts to shareholders. Because the unit of analysis in agency theory is a contract that underlies the relationship between principal and agent, the focus of this theory is on determining the most efficient contract that underlies the relationship between principal and agent.

The demand for compliance with the timeliness in submitting the annual financial statements of public companies in Indonesia has been regulated in Law No. 8 of 1995 concerning the Capital Market. Bapepam and LK also issued regulation Number: KEP-431 / BL / 2012 with attachment Number X.K.6 until the transfer of Bapepam to become OJK. These regulations legally imply compliance with the behavior of individuals and organizations (public companies) involved in the Indonesian capital market to deliver the company's annual financial reports in a timely manner. These regulations are in accordance with the compliance theory proposed by Tyler (1990). The theory of compliance has been studied in the social sciences, especially in the fields of psychology and sociology, which emphasizes the importance of the process of socialization in influencing an individual's compliance behavior. Signal theory suggests how companies should provide signals to users of financial statements. This signal is in the form of information about what has been done by management to realize the wishes of the owner. Signals can be in the form of promotions or information stating that the company is better than other companies. According to Hanafi and Halim (2005) that companies that have confidence in good prospects going forward will tend to communicate the news to investors. So that a company that has good quality will provide a signal by delivering the company's financial statements on time. Whereas poor quality companies will be late in delivering financial reports. Financial reporting is a vehicle for companies to communicate various information and measurements economically regarding the resources owned by the company and the company's performance to various parties who have an interest in the information (Belkauoi, 2006). Financial reporting is 
expected to provide relevant information about the company's financial performance for one period and the information presented can help investors who want to invest their capital into the company and to obtain relevant and reliable information, it requires timeliness in its presentation.

\section{MATERIAL AND METHODS}

The method used in collecting research data is: documentation method. The documentation method is the method used in this study by collecting financial records or reports taken through the Indonesia Stock Exchange (IDX) website. The data taken is secondary data in the form of the company's annual financial reports on transportation companies listed on the Indonesia Stock Exchange (IDX) by downloading the audited financial statements from 2017 to 2021 through the website (www.idx.co.id). Dependent variable (dependent variable), which is a variable that has a dependency between variables with one another. The dependent variable in this study is: the timeliness of submission of financial statements. Timeliness is the time span between the date of the company's financial statements and the date when financial information is announced to the public relating to the quality of financial information reported. The company is categorized on time if the financial statements are submitted no later than the end of the financial statement date (April 30/120 days) or after the financial year ends in accordance with the regulations of Bapepam-LK or OJK.

\section{RESULT AND DISCUSSION}

\section{Effect of Profitability on the Timeliness of Submitting Financial Statements.}

The results of the logistic regression test indicate that the variable profitability of the company influences the timeliness of the submission of financial statements. This can be seen from the hypothesis test where the value of profitability is significant at 0.015 , where 0.015 is smaller than the significance level $(0.015<0.05)$. Thus this study accepts the first hypothesis (H1) which states that profitability has a positive effect on the timeliness of financial statement submission.

In the descriptive statistics table the results show that the average sample company experiences a gain of 0.58245. Even though the sample company experiences a fairly small profit on average, it does not affect the company to not be timely in submitting its financial statements. Also seen in the standard deviation value and the average level of profitability of the sample company has a distance value that is not far away, namely the standard deviation of 0.1175758 and the average company profitability of 0.58245 this causes the results of the test to be significant. 
From the 150 data observations obtained the minimum value for the smallest amount of profitability owned by the company is equal to -0.25 , namely by PT. Blue Bird Tbk in 2011, meaning the company experienced a decline in profits. The smaller the company's profit, the more the company will deliver the customer report. While the maximum value owned by the company observation is equal to 0.64, namely by PT. ICTSI Jasa Prima Tbk in 2011, means experiencing increased profits. The higher the company's profit, the more timely the financial statement will be. This value indicates that the level of profitability obtained by the company is between -0.25 to 0.64 .

The findings in this study support the existing theoretical logic, which states that profitability shows the success of the company in generating profits. The higher the level of profitability a company will quickly submit its financial statements. Companies that have high profitability contain good news and companies that experience good news will tend to deliver timely financial reports to interested parties.

\section{The Effect of Leverage on the Timeliness of Submitting Financial Statements.}

The results of the study using logistic regression showed that financial leverage did not affect the timeliness of financial statement submission. This can be seen from the calculation value of the hypothesis test where the significance value of leverage is 0.425 greater than the significance level of $5 \%(0.425>0.05)$. Thus this study can accept the second hypothesis $(\mathrm{H} 2)$ which states that leverage has a negative effect on the timeliness of financial statement submission. This hypothesis test is in accordance with the results of research by Kuswanto and Manaf (2015) which states that leverage variables have no significant effect on the timeliness of financial statement submission.

The results of the descriptive statistics of the study also obtained results that the average level of company leverage that became the sample of the study was quite low at 1.2226. The distance between the standard deviation value and the average leverage is not far enough, where the standard deviation value is 1.92522 and the average value of leverage is 1.2226 , which causes the results of the test to be insignificant. The minimum value of leverage is 0.15 which means that the company has the ability to pay its debt of 0.15 , namely by PT. Adi Sarana Armada Tbk in 2011, the smaller the company's leverage value, the company will be on time to submit its financial statements. While the maximum value owned by the observation company is 14.25 , namely by PT. Humpuss Intermoda Transportasi Tbk in 2011, showed that the higher the company's leverage, the company will be late in delivering its financial statements. This value indicates that the level of leverage obtained by the company is between 0.15 to 14.25 . 
This means that this study shows that the high and low level of financial leverage of a company does not affect the timeliness of financial statement submission. This shows that companies that have a high level of financial leverage also want to deliver their financial statements on time, this serves so that creditors can find out the company's performance and know the company's ability to pay loans from creditors. If the company postpones its financial statements, it will reduce the level of creditor trust in the company in the ability to repay the company's debt. This is not in accordance with the existing logic of the theory, thus companies that are timely or not timely in submitting their financial statements do not consider the level of financial leverage experienced by the company.

\section{Effect of Liquidity on the Timeliness of Submitting Financial Statements.}

The results of the logistic regression test show that the liquidity variable influences the timeliness of financial statement submission. This can be seen from the hypothesis test where the significant value of liquidity is 0.035 . The logistic regression coefficient for the positive liquidity variable is 0.387 from these results. It can be concluded that the significance of the liquidity variable is smaller than the specified significance level, which is equal to $5 \%(0.035<0.05)$. Thus this study accepts the third hypothesis (H3) which states that liquidity has a positive effect on the timeliness of financial statement submission.

In the descriptive statistics table the results show that the average level of liquidity of the sample companies experiences a gain of 0.56082 . Even though the sample company experiences a fairly small profit on average, it does not affect the company to not be timely in submitting its financial statements. Also seen in the standard deviation value and the average level of liquidity of the sample company has a distance value that is not far, namely the standard deviation of 0.1056961 and the average company liquidity of 0,56082 this causes the results of the research test to be significant.

The minimum value of liquidity is 0.31 , meaning that the company has the ability to pay off its short-term liabilities at maturity of 0.31 , namely by PT. Tanah Laut Tbk in 2011, the lower the level of liquidity, the company cannot fulfill its short-term obligations properly and will be late in submitting its financial statements. While the maximum value owned by the observation company is 14.99, namely by PT. Trada Maritime Tbk in 2011, showed that the higher the company's liquidity, the company can fulfill its short-term obligations well and will be on time to submit its financial statements. This value indicates that the level of liquidity obtained by the company is between 0.31 to 14.99 . 
This shows that with a high level of liquidity in a company, the company can fulfill its short-term obligations well and provide good news for companies and creditors, and can influence the company to deliver its financial reports on time because it will make market reaction is positive for the company.

\section{Effect of Company Size on the Timeliness of Submitting Financial Statements.}

The results of the study using logistic regression showed that the size of the company did not affect the timeliness of the submission of financial statements. This can be seen from the hypothesis test where the value of firm size is significant at 0.238 where 0.238 is greater than the significance level $(0.238>0.05)$. Thus this study cannot accept the fourth hypothesis (H4) which states that the size of the company has a positive effect on the timeliness of the submission of financial statements. The minimum value of company size is 0.51 indicating the size of the company, namely by PT. ICTSI Jasa Prima Tbk in 2011, meaning that the smaller the size of the company, the company will be late in submitting its financial statements. While the maximum value owned by the observation company is 2.9482, namely by PT. Indonesia Transport \& Infrastructure Tbk in 2011, showed that the greater the size of the company, the company will be on time in delivering its financial statements. This value indicates that the size of the company obtained by the company is between 0.51 and 2.9482 .

Thus the results of the study are not in accordance with the theory described, which states that companies are said to be large if the company has large total assets and large companies will be on time to submit their financial statements. The fact is that large companies do not rule out the possibility of being late in submitting financial reports. Likewise with small companies that can deliver timely financial reports.

\section{Effect of Auditor Opinion on the Timeliness of Submitting Financial Statements.}

The results of the study using logistic regression get the results that the auditor's opinion affects the timeliness of the submission of financial statements. This can be seen from the hypothesis test where the auditor's opinion value is significant at 0.041 where 0.041 is smaller than the significance level $(0.041<0.05)$. Thus this study can accept the fifth hypothesis (H5) which states that auditor opinion has a positive effect on the timeliness of submission of financial statements.

The minimum value of the auditor's opinion is 0.00 indicates the auditor found evidence that is not in accordance with generally accepted accounting principles by PT. Berlian Laju Tanker Tbk in 2011, meaning that the possibility of 
an opinion issued can affect the audit completion time of the company will be late in submitting its financial statements. While the maximum value possessed by the observation company is 1.00, namely by PT. Adi Sarana Armada Tbk in 2011, showed that the auditor gave an unqualified opinion on the financial statements provided by the company, the company would be on time to submit its financial statements. This value indicates that the auditor's opinion obtained by the company is between 0.00 and 1.00 .

The test results show a positive relationship between audit opinion and the timeliness of financial statements, meaning that companies that receive audits with unqualified opinions from auditors for their financial statements tend to be more timely in submitting their financial statements. This is because the timeliness of the submission of financial statements is related to the auditor's opinion, where the auditor who provides unqualified opinions makes the company good news so that it will be timely in delivering its financial statements.

\section{The Reputation Effect of KAP on the Timeliness of Submitting Financial Statements.}

The results of the study using logistic regression obtained results that the reputation of the KAP did not affect the timeliness of the submission of financial statements. This can be seen from the hypothesis test where the reputation value of KAP is significant at 0.217 where 0.217 is greater than the significance level $(0.217>0.05)$. Thus this study cannot accept the sixth hypothesis (H6) which states that the reputation of KAP has a positive effect on the timeliness of financial statement submission. KAP's minimum reputation value is 0.00 , indicating that the company does not use KAP services, including the Big Four by PT. Berlian Laju Tanker Tbk in 2011, meaning that the company uses the services of a small accounting firm and this will affect the timing of its financial statements. While the maximum value possessed by the observation company is 1.00, namely by PT. Adi Sarana Armada Tbk in 2011, showed that the company used the services of a large accountant or incorporated in the Big Four because it had a good reputation so that the quality of the audit produced was better, the companies that used large KAP services tended to deliver timely financial reports. This value indicates that the reputation of the KAP obtained by the company is between 0.00 and 1.00 .

The results of this study are in line with the research conducted by Hilmi and Ali (2008), but it is inversely proportional to the research conducted by Kuswanto and Manaf (2015), Ovami (2014) which shows that the reputation of KAP influences the timeliness of financial statement submission. Then it can be interpreted that the reputation variable KAP does not have a significant effect on 
the timeliness of the submission of financial statements. The test results show that the accuracy of the submission of the company's financial statements is not determined by whether or not the reputation of the auditor has a quality audit. In this study, empirical evidence was found that most of the transportation companies listed on the Indonesia Stock Exchange were on time in submitting the company's financial statements to Bapepam and OJK. This shows that the company's high awareness in complying with laws and regulations in the field of capital markets, particularly regarding the principle of openness in the capital market in the form of timely submission of financial statements. Besides that, it also shows the magnitude of the company's responsibility towards those interested in the company's financial statement information.

Based on the results of the research conducted statistically, it produces several things that need to be considered regarding the effect of profitability, leverage, liquidity, company size, auditor opinion and KAP reputation on the timeliness of financial statement submission. The logistic regression test results from table 5.3 can be seen that the magnitude of the Hosmer and Lemeshow Test (Goodness-of-Test) statistic is 10,245 and the degree of feedom is 9 with a significance probability of $0.341(0.341>0.05)$. Thus H0 is accepted, so it can be concluded that the logistic regression model used has met the data adequacy (fit)

\section{CONCLUSION}

Based on the results of research and discussion, conclusions can be drawn in accordance with the formulation of the problem as follows:

1. Profitability has a positive effect on the timeliness of submission of financial statements.

2. Leverage has a negative effect on the timeliness of submission of financial statements.

3. Liquidity has a positive effect on the timeliness of the submission of financial statements.

4. The size of the company does not affect the timeliness of the submission of financial statements, meaning that rejecting $\mathrm{H} 4$ states that the size of the company partially has a positive effect on the timeliness of submission of financial statements.

5. Auditor's opinion has a positive effect on the timeliness of submission of financial statements.

6. The reputation of KAP does not affect the timeliness of submitting financial statements. Thus, the results of the study found empirical evidence that the variables of profitability, liquidity and auditor opinion influence the timeliness of financial statement submission. The results of this study can be 
used by financial analysts, management, and creditors to predict the timeliness of submission of financial statements of a company.

\section{REFERENCES}

Belkaoui, Ahmed Riahi, 2006. Teori Akuntansi, Edisi Kelima, Terjemahan Ali Akbar Yulianto, Risnawati Dermauli, Salemba Empat, Jakarta.

Hanafi, M Mamduh. dan Abdul Halim. 2005. Analisis Laporan Keuangan. Edisi Kedua. Yogyakarta: UPP AMP YKPN.

Jensen, M.C. and Meckling, W.H.1976."Theory of Firm Managerial Behaviour Agency Cost \& Ownership Structure" Journal of Financial Economics.3.Pp.305-306. (diakses tanggal 16 Maret 2017).

Kuswanto, Hedy dan Sodikin, Manaf. 2015. Faktor-Faktor yang Mempengaruhi Ketepatan Waktu Penyampaian Laporan Keuangan ke Publik (Studi Empiris Pada Perusahaan Manufaktur yang Terdaftar di Bursa Efek Indonesia Periode 2010-2013). Dosen STIE Dharmaputra. Semarang. (diakses tanggal 25 April 2017).

Tyler, Tom R. 1990. Why people obey the law. New Haven, CT: Yale University Press. (diakses tanggal 16 Juli 2017).

Undang - Undang No.8 Tahun 1995 tentang Peraturan Pasar Modal 